\title{
Preparation of Sandy Soil Stabilizer for Roads Based on Radiation Modified Polymer Composite
}

\section{H. H. Elnahas}

Radiation Research of Polymer Dept., National Centre for Radiation Research and Technology (NCRRT), Egyptian Atomic Energy Authority), P. O. Box; 29 Nasr City, Egypt.

\footnotetext{
D ADIATION modified polymer composite (RMPC) was Rstudied to build an extremely durable sandy road, construct a trail or bath, or control dust and erosion. A dilute solution of composite binds sandy soil fines through a coagulation bonding process.

The result is a dense soil structure that has superior resistance to cracks and water penetration and can also solve erosion control problems. In erosion control applications, diluted composite is merely sprayed into sandy soil without compaction, effectively sealing the surface to prevent air-born dust or deterioration from erosion.

The prepared composite has an elastic and melt-able film formation that imparts thermal compacting to the stabilized sandy soil after full dryness for sandy road leveling, repairing and restoration processes. The prepared composite is environmentally economical when compared with traditional sandy soil stabilizing (SSS) or sealing methods.

Keywords: Sandy soil stabilizer, composite, radiation.
}

Sandy soils are problematic for stabilization and often require cement and/ or asphalt emulsion to provide cohesion for the soil (Santoni et al., 2003, Zandieh et al., 2010 and Vvedenskaya et al., 1971). However, there are a variety of nontraditional soil stabilization/modification additives available from the commercial sector such as polymer emulsions (Taytak et al., 2012 and Mitchell et al., 2005) acids, lignin derivatives, enzymes, tree resin emulsions and silicates (Rauch et al., 2003). The US Army research effort has been narrowed from evaluating a wide number of soil stabilization / modification additives (Santoni et al., 2003) to a focus on additives with particle binding properties (cement, polymer emulsions, etc.). Stabilization of soils using polymer emulsion is a straight forward process in that the liquid is simply diluted to the proper amount. 
The dilution amount is selected to achieve the target additive quantity at the desired moisture content required for the most efficient compaction of the soil (Abolarin et al., 2010 and Liu et al., 2010). The application conditions must be well controlled to insure that the proper amount of stabilizer is delivered into the soil and to achieve the proper moisture content for wet compaction (Taytak et al., 2012 and Mitchell et al., 2005). A typical polymer emulsion contains approximately 45-50 wet\% polymer (Vvedenskaya et al., 1971), 1-2\% emulsifier with the balance being potable water (Santoni et al., 2003). The polymer may also be highly variable in its chemistry (i.e. styrene-butadiene or polyethylene-vinyl acetate), molecular wt, degree of branching, side-chain size and composition, etc. Typically, a polymer for soil stabilization should have excellent physical properties such as high tensile, flexural, and compressive strength. Most of polymer products touted for soil stabilization are vinyl acetate or acrylic-based copolymers (Zandieh et al., 2010 and Vvedenskaya et al., 1971).

The aim of this work is to demonstrate an emulsion type of polymer composite and to recognize that imparts significant thermal compacting and water prevention to the stabilized sandy soils.

\section{Experimental}

\section{Material}

Vinyl acetate Versatic Ester (VAcVe) in the form of copolymer emulsion with 50\% solid content and styrene monomer from Vinavile Co., Italy, Polyvinyl alcohol (PVA) from Kurary Co., Japan, Dibutylphthalate (DBP) from Aldrich Co., Germany, Hydroxy Ethyl Cellulose (HEC) from Rhom and Hass Co., Calcium oxide (hydrated) from El-nasr for phosphate Co., Egypt.

\section{Preparation of samples}

The following typical formulation of sandy soil stabilizer-sand (SSS-Sand) combination samples were molded by using $2.5 \mathrm{~cm}$ cubic cavities according the following ratios: $100 \mathrm{~g}$ of $\mathrm{VAcVe}, 30 \mathrm{~g}$ of RMPC, $100 \mathrm{~g}$ of water and $800 \mathrm{~g}$ of sand.

\section{Preparation of RMPC}

a) Styrene monomer: 5g, DBP: 5g, Sulphonic acid: $0.1 \mathrm{~g} \&$ PVA (8\% in water): $5 \mathrm{~g}$. 
b) HEC ( $1 \%$ in water): $5 \mathrm{~g} \&$ Calcium oxide (hydrated): $10 \mathrm{~g}$.

where, compound (a) contains Styrene monomer, DBP as a plasticizer, sulphonic acid as an emulsifier and PVA as a protective colloid to prevent the emulsified styrene monomer molecules to approach to the critical distance to coagulate during the polymerization process by using $\gamma$-rays, the compound was stirred will till all the ingredients become in a homogeneous light paste. Compound (b) contains a solution of $1 \%$ of HEC and Calcium oxide with and was stirred till Calcium oxide becomes in a full dispersion. Compound (b) was added to compound (a) with a slow rate of stirring till the homogenization is occurred. Mixture of (a) and (b) was then irradiated through $\gamma$-rays at 10kGy, where a white and light paste of RMPC was obtained. The compound of SSS containing VAcVe and RMPC was diluted with water to the appropriate concentration to obtain the optimum moisture content for the sand combination process. The main function is concluded through the following:

i- VAcVe as a copolymer emulsion for possessing a film form property, cohesion strength between sand particles and water penetration prevention.

ii-RMPC based on emulsified and plasticized styrene monomer for possessing a thermal softening property to $\mathrm{VAcVe}$ through the dry-thermal compaction process, where sand particles become sticky and cohesive, providing a necessary condition for stabilization.

iii- Calcium oxide (hydrated) for reducing drying time, increasing surface hardness of VAcVe film forming and also in addition it acts as antiseptic agent to the polymer composite-sand combination (Rauch et al., 2003 and Santoni et al., 2003).

\section{Preparation of dried mould samples}

The material of SSS-Sand was placed in five layers, and each layer was hand-rotted 25 times with steel rod to reduce the loose height of the material. This was necessary to ensure that all of the loose material would fit within the cubic compaction mold. The samples were then placed in a temperature controlled room where they were allowed to cure at $23^{\circ} \mathrm{C}$ and $50 \%$ relative humidity for various cure time. The curing process could be considered an airdried by the evaporation of moisture from the specimens over time.

Egypt. J. Rad. Sci. Applic., Vol. 29, No. 1-2 (2016) 


\section{Characterization}

\section{Sample irradiation}

Irradiation was carried out using a cobalt-60 source of $\gamma$-rays manufactured by the Atomic Energy Authority of India, with a dose rate of $2 \mathrm{kGy} / \mathrm{h}$.

\section{Hardness test}

Surface hardness was measured by using ASTM D 2240 specifications, model 306L type A, D durometer for soft and hard plastic.

\section{Water absorption}

Water absorption measurements were made by using clean and dried samples of known wt, which were immersed in distilled water for $24 \mathrm{~h}$ at $25^{\circ} \mathrm{C}$. The samples were removed, blotted with absorption paper and quickly weighted. The water absorption (\%) of sample was calculated as:

$$
\text { Water absorption }(\%)=\left(\mathrm{W}_{\mathrm{e}} / \mathrm{W}_{\mathrm{d}}\right) 100 .
$$

Where, $\mathrm{W}_{\mathrm{e}}$ is the wt of sample at equilibrium and $\mathrm{W}_{\mathrm{d}}$ is the wt of dried sample before swelling.

\section{Compaction test}

The test of compaction was measured as a test of compression percent of initial thickness where the load of $100 \mathrm{Kg}$ per cc area was applied for $1 \mathrm{~min}$ and the residual thickness of cubic mould was measured as the follows:

Compaction \%= (residual thickness/ original thickness)x 100.

\section{Compressive strength}

The machine of compressive strength was Instron 1100 type, England. Compressive strength was calculated as the load required per area to break down the sample $\left(\mathrm{Kg} / \mathrm{cm}^{2}\right)$.

\section{Abrasion test}

AP.40 (Maschinebau Gmbh Raueustein Thuringeu, Germany) which has the following specification: Cylinder diameter: $150 \mathrm{~mm}$, Cylinder length: $560 \mathrm{~mm}$, Cylinder speed: 40rpm, Specimen diameter: $16 \mathrm{~mm}$, Specimen clamping height: $15 \mathrm{~mm} \&$ Abrasion path: 40meters. 
Where, loss in the mass was calculated according to the following equation:

$$
\text { Mass loss (mg) per revolution }=\left[\left(\mathrm{W}_{\mathrm{i}^{-}}-\mathrm{W}_{\mathrm{f}}\right) / \mathrm{n}\right] \mathrm{X} 100 .
$$

Where, by $\mathrm{W}_{\mathrm{i}}$ is the original mass of sample $(\mathrm{g}), \mathrm{W}_{\mathrm{f}}$ is the final mass of sample $(\mathrm{g})$ and $\mathrm{n}$ is the number of revolution (84).

\section{Scanning electron microscopy (SEM):}

The SEM was used for investigation the internal fracture morphology of samples bulks and this analysis were carried out with a JSA. 5400 Jeol, Japan.

\section{Results and Discussion}

\section{Compaction behaviour}

The wet compacted samples of polymer composite-sand combination were cured under controlled temperature and humidity conditions, at $25^{\circ} \mathrm{C}$ and $50 \%$ relative humidity. The curing process allowed the samples to air-dry prior to testing. Sand-polymer composite at emulsion percent solids levels of $3.2 \% \mathrm{wt}$ of solids to wt of polymer composite-sand combination, where a level of $3.2 \%$ was chosen as a convenient basis emulsion and was based on the optimum emulsion additive concentration from previous research and also experimental trials efforts (Santoni et al., 2003).

\section{Compaction effort process}

Compaction effort is the process of physically increasing the wt per unit volume of sandy soil road. Normally, without a proper moisture level, compaction cannot occur successfully. If too wet, the compacted soil will push out from under the compaction equipment and, if too dry, the compacted soil will not hold together and any successive compaction will cause soil cracking because it will lack the cohesive, "sticky" quality mentioned above in "moisture content".

\section{Dry compaction behaviour of polymer composite-sand combination}

As mentioned, in traditional conditions of sandy soil stabilizers, if the material dries out after wet compaction, the additional compaction at excessive loading will cause cracking .Fig. 1. shows the effect of adding the radiation modifier compound for allowing the road base (polymer composite-sand combination sample) more soft at $90^{\circ} \mathrm{C}$ with a greater strength for dry compaction.

Egypt. J. Rad. Sci. Applic., Vol. 29, No. 1-2 (2016) 


\section{Wet compaction}

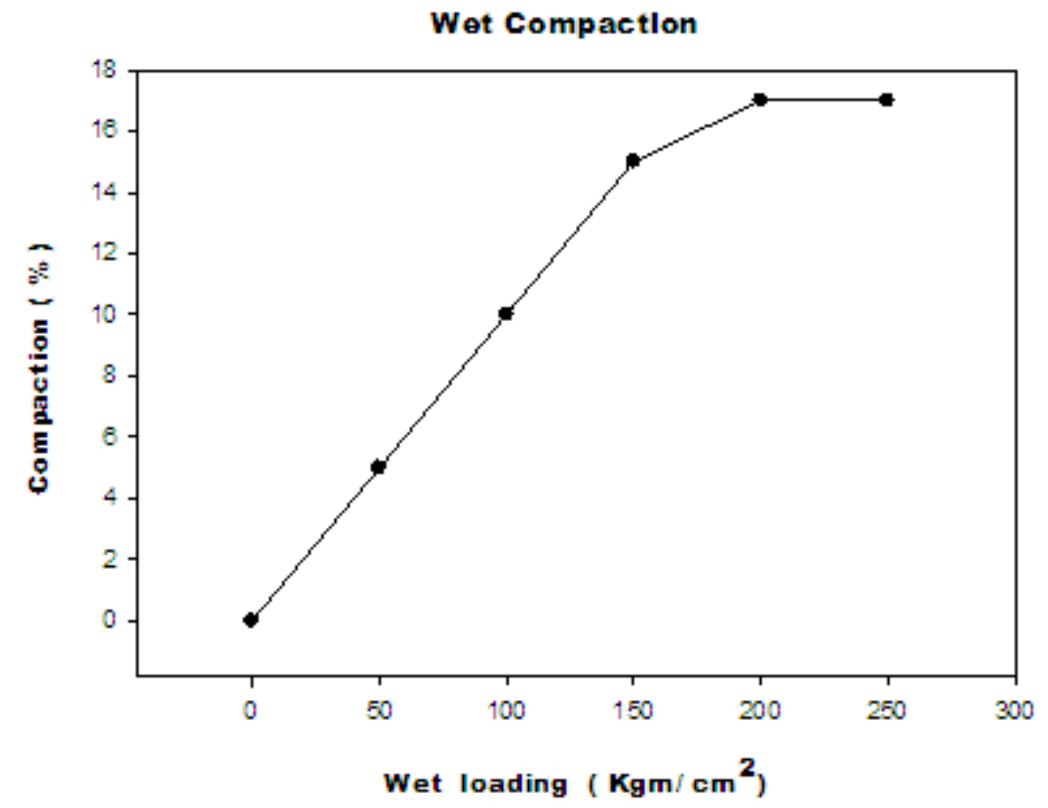

Fig.1. Effect of wet loading on compaction percent of SSS-Sand combination.

Fig. 2. the use of compact-ability behavior for SSS (polymer composite-sand combination sample) provides a convenient bases for testing and is a quick and simple test for comparative analysis. However, when comparing materials that demonstrate brittle failure (cement and gypsum) to those fail in ductile fashion, as many materials do (Zandieh et al., 2010). Compaction is a measure of the reduction by the sample per unit volume, in this case, up to the yield point.

The yield point is defined here as the point of maximum compaction (reduction in volume or thickness) through a determined thermal loading.

Fig. 3. shows the effect of Dry-thermal compaction to produce an increase in sand particles cohesion, where the denser the soil, the stronger the cohesion, or in other words as soil undergoes more stable compaction and cohesion than those obtained from wet or dry compaction and prevents in sequences dust when dry, and decreases the soil loss and deterioration of material properties at high application uses. 


\section{Dry compaction}

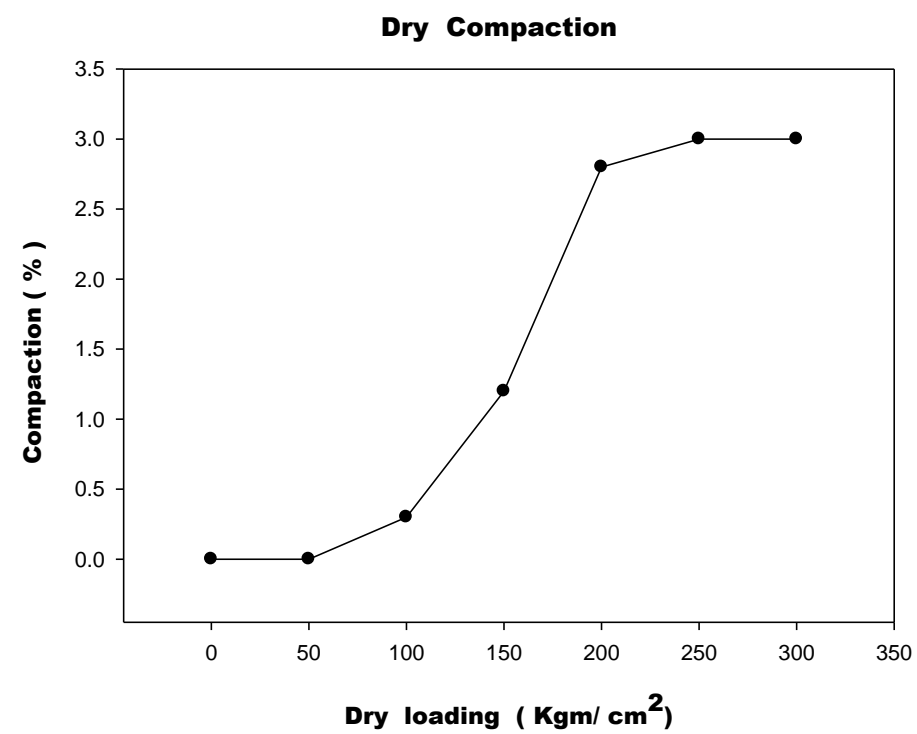

Fig.2. Effect of dry loading on compaction percent of SSS-Sand combination. Dry-thermal compaction

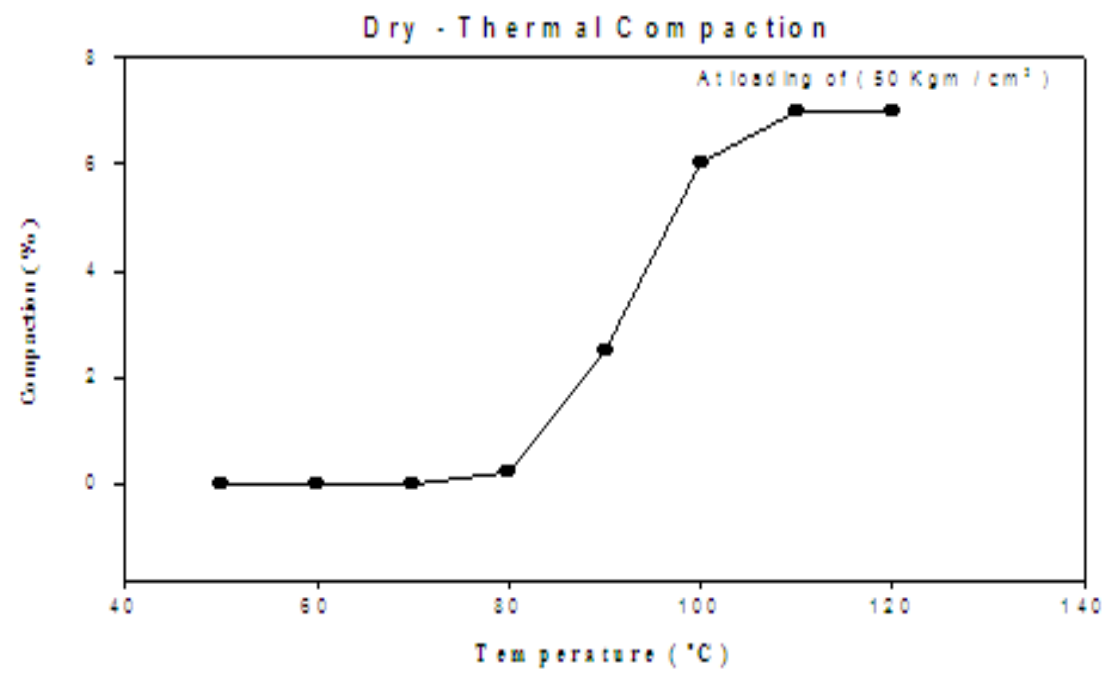

Fig. 3. Effect of temperature as a function of dry thermal loading on compaction percent of SSS-Sand combination.

Egypt. J. Rad. Sci. Applic., Vol. 29, No. 1-2 (2016) 
The Dry-thermal compaction resists water penetration through sand grains and consequently generates protective grains less susceptible to water than those obtained from wet and dry compaction.

\section{Effect of aging time}

Fig. 4. shows effect of aging time of exposure to sunlight for a period (6month) in summer season (from May to October) in Cairo region at temperature $20-35^{\circ} \mathrm{C}$

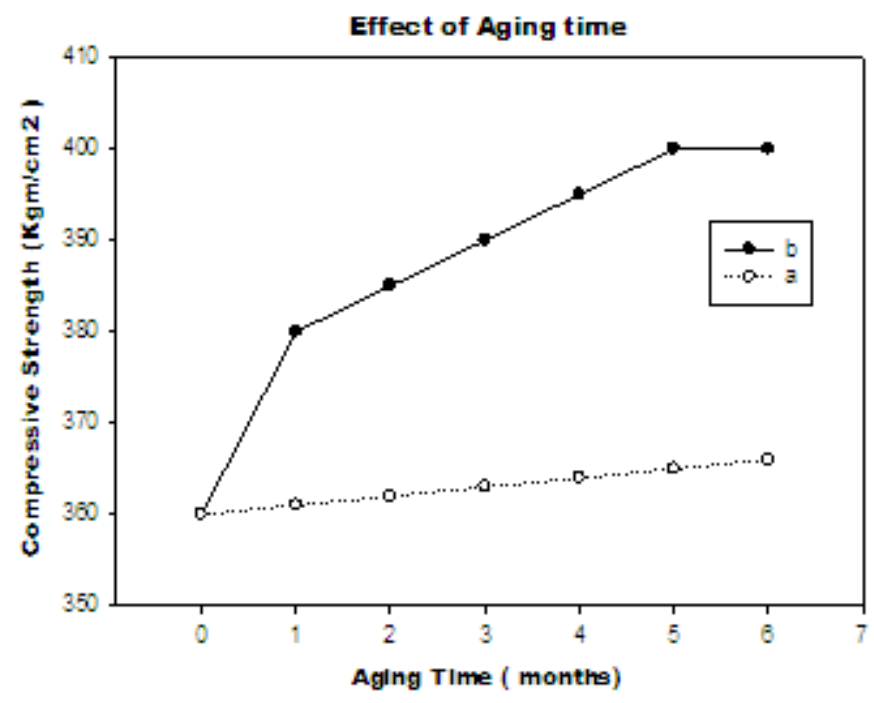

Fig. 4. Effect of aging time as a function of exposure to the direct sunlight on compressive strength of SSS-Sand combination.

In direct sunlight and after six months, no changes were apparently appear in compressive strength through the samples which are not having RMPC but all samples having RMPC have achieved an increase in compressive strength. Where, strength will depend on the magnitude of interfacial adhesion forces that will develop between the sand particles and the polymers of SSS matrix. These forces are between the constituents of the SSS-Sand combination. The reason of this are arising from the fact that styrene molecule is considered to be highly resistant to ultra violet radiation of direct sunlight, as the vinyl double bond is conjugated with the phenyl ring. It follows that all carbon atoms are located in the same plane and owing to the delocalization of electrons; any excess energy 
corresponding to an exited state derived from this structure will be randomly distributed over the whole molecule (Mitchell et al., 2005, Taytak et al., 2012 and Rauch et al., 2003). Also the trend of compressive strength showed more to those observed after one month of curing. It is intended to be a predictor of durability properties related to day and night as a different temperature condition and also to give a simple indicator of how well a stabilizer responds to the hot weather in summer season.

\section{Effect of RMPC on sandy soil stabilizer-sand combination}

Surface hardness, abrasion and water absorption data are presented as a function of RMPC addition in Fig. 5, $6 \&$ 7. All of the increased of RMPC in SSS-Sandy combination exhibit higher hardness, less abrasion and less water absorption. The data reported indicated that RMPC significantly improve hardness, abrasion and water absorption at addition levels of $4 \mathrm{phr}$ which are considered as optimizing additive levels and for the better-performing emulsion polymer for SSS.



Fig. 5. Effect of RMPC on surface hardness of SSS-Sand combination.

Egypt. J. Rad. Sci. Applic., Vol. 29, No. 1-2 (2016) 


\section{Surface hardness}

Fig. 5. shows an obvious increase in surface hardness with increasing RMPC till it reaches the maximum hardness at 4phr of RMPC.

\section{Abrasion test}

On comparing the results presented in Fig. 6. it may be observed that the values of wt loss in case of SSS having RMPC lies less than that in sandy soil stabilizer without RMPC and wt loss apparently decreased with increasing the amount of RMPC added.

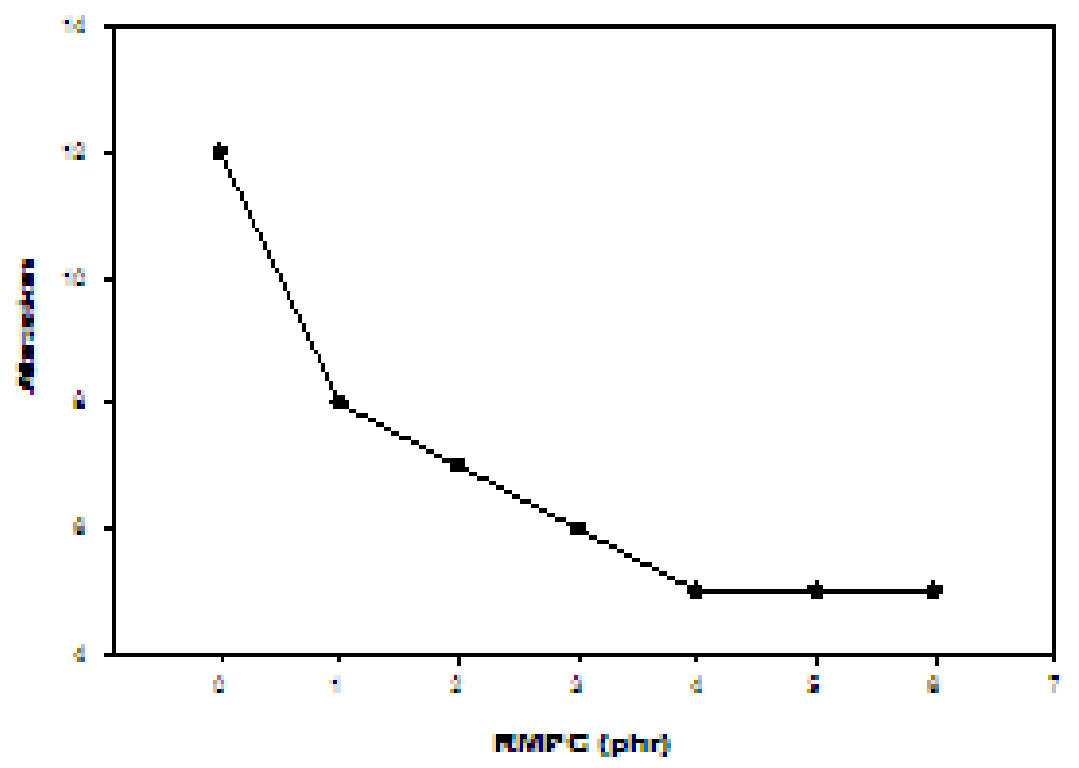

Fig. 6. Effect of RMPC on abrasion of SSS-Sand combination.

\section{Water absorption}

Water absorption percentage is a function of hydrophilic properties of the SSS as an emulsified polymer, from the Fig. 7. the results showed that water absorption values decreased by increasing the amount of RMPC added to the VAcVe. After seven days of curing, the trend in water absorption was slightly increased than those observed after one day of curing. 




Fig. 7. Effect of RMPC on water absorption of SSS-Sand combination.

\section{Scanning electron microscopy (SEM)}

The following SEM views of dry SSS-Sand samples in Fig. 8. are representing a dry sample after wet compaction process (view-A) and a dry sample after a dry-thermal compaction process (view-B), where in view-A irregular cavities and holes between sand particles and more rough surfaces are obviously shown, but view-B, represents a dry sample after holding three different processing of compaction through wet compaction process then left to full dryness then dry compaction process and finally dry-thermal compaction at $90^{\circ} \mathrm{C}$. The observation suggests that might be exist physical compaction to reduce the irregular cavities and holes and a uniformly distributed sand particle within the matrix was noted.

The result of that, it is a well-known fact that the less regular the surface the higher will be the loading was absorbed through stabilized sand particles after applying a dry-thermal compaction process.

Egypt. J. Rad. Sci. Applic., Vol. 29, No. 1-2 (2016) 


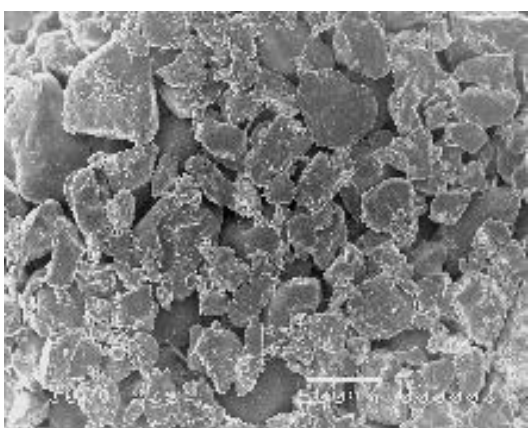

View A

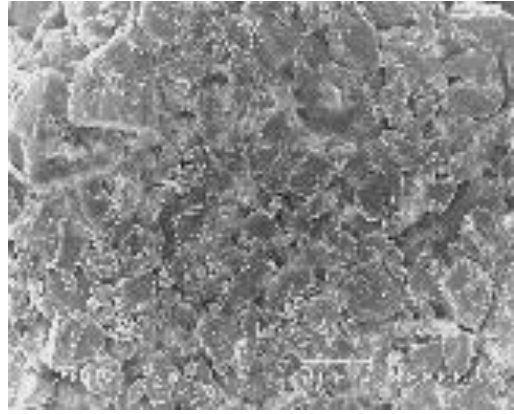

View B

Fig. 8. SEM-scanning electron microscope.

\section{Conclusion}

The study offers soil-polymer systems that often do not fail in a brittle fusion and deform to higher dry compaction than soil-cement. The methodology employed in this work only capture the thermal dry compaction up to the yield point, where the result is a dense soil structure that has superior resistance to cracks and water penetration and can also solve erosion control problems. Also, the prepared composite has an elastic and melt-able film formation that imparts thermal compacting to the stabilized sandy soil after full dryness at $90 \mathrm{OC}$ for sandy road leveling, repairing and restoration processes.

\section{Acknowledgements}

The author expresses his gratitude to GOLF Company for their contribution to the experimental program of this study.

\section{References}

Abolarin, M. S., Lawaland A. and Salawu, A. A. (2010) Effect of Moisture Content on the Moulding Properties of River Niger Sand Using Tudun-Wada Clay as a Binder, $A U$ J. T., 13, 170.

Zandieh, A. R. and Yasrobi, S. S. (2010) Study of factors affecting the compressive strength of study soil stabilized with polymer Geotechn. Geologic. Engineer., 28, 139.

Liu, S., Cao, W., Li, Y. and Yang, Y. (2010) An analysis of slope stability of sand embankment with shear strength reduction (SSR) method. Adv. Mater. Res. 152-153, 1017.

Mitchell, J. K. and Santamarina, J. C. (2005) Biological considerations in Geotechnical Engineering. J. Geotech. Geoenviron. Engineer., 131, 1222.

Egypt. J. Rad. Sci. Applic., Vol. 29, No. 1-2 (2016) 
Rauch, A. F., Harman, J. S., Katz, L. E. and Liljestrand, H. M. (2003) Measured effects of liquid soil stabilizers on engineering properties of clays. Transport Res. Record, 1787, TRB, National Research Council, Washington, DC, pp. 33-41.

Santoni, R. L., Tingle, J. S. and Webster, S. L. (2003) Stabilization of silty sand with non-traditional additives. Transport Res. Record, 1787, TRB, National Research Council, Washington, DC, pp. 33-41.

Taytak, B., Pulat, H. F. and Yukselen-Aksoy, Y. (2012) Improvement of Engineering Properties of Soil by Biopolymer Additives, $3^{\text {rd }}$ International Conference of New Developments in Soil Mechanics and Geotechnical Engineering, Near East University, Nicosia, North Cyprus.

Vvedenskaya, V. A., Ogneva, N. E., Korshak, V. V., Mekhant'eva, L. I. and Goguadze, Ts. A. (1971) Translated by E.A. Inglis. Consolidation of OverMoist Soils by Copolymers of Guanidine Acrylate and MethacryloguanidineUrea Hydrochloride with Certain Alkylidene Bisacrylamides. In Soviet Plastics, Vol. 7, Rubber and Technical Press, London, England, pp. 55-58.

(Received: 16/11/2015;

accepted: 06/03/2016)

Egypt. J. Rad. Sci. Applic., Vol. 29, No. 1-2 (2016) 


$$
\begin{aligned}
& \text { تحضير مثبت للتربة الرملية لرصف الطرق بأسـاس خليط من } \\
& \text { بوليمرات محورة اشعاعيا } \\
& \text { حسين حسين النحاس } \\
& \text { قسم البحوث الإثعاعية لكيمياء البوليمرات ، المركز القومى لبحوث وتكنولوجيا } \\
& \text { الاشعاع ، ص. ب. 9r مدينة نصر. }
\end{aligned}
$$

الهذف من هذة الدراسة تحضبر خلبط من بوليمر ات محورة اثـعاعيا

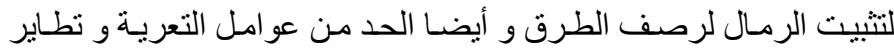

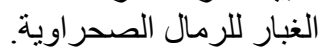

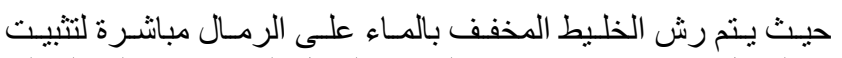

حبيبات الرمال و زيادة تر ابطها بعد الجفاف الكامل الناتج عن عملية التجلط

$$
\text { للخليط. }
$$

أثنتـت الدر اسـة ان عينـات الرمـال المثبتة بخليط البوليمر ات المحورة

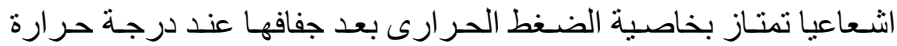

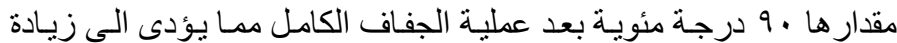



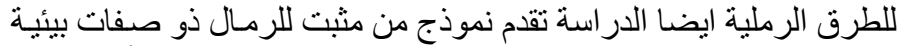

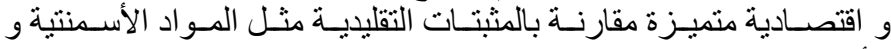

الأسفلتية.

Egypt. J. Rad. Sci. Applic., Vol. 29, No. 1-2 (2016) 